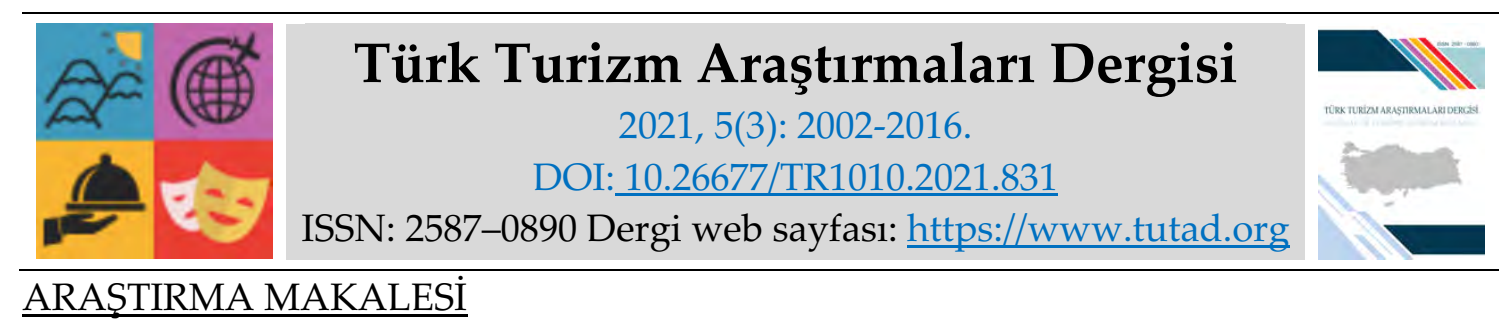

\title{
Çalışanların Sosyo-Demografik Özelliklerinin Mutluluğa Etkisi: Antalya'daki Otel İşletmelerinde Bir Uygulama
}

Doç. Dr. Boran TOKER, Akdeniz Üniversitesi, Serik İşletme Fakültesi, Antalya, e -posta: borantoker@akdeniz.edu.tr

ORCID: https://orcid.org/0000-0002-4658-1934

Öğr. Gör. Dr. M. Bahadır KALIPÇI, Akdeniz Üniversitesi, Manavgat Meslek Yüksekokulu, Antalya, e-posta: bkalipci@gmail.com ORCID: https://orcid.org/0000-0001-7310-890X

$\ddot{O} z$

Bu çalışmada, turizm çalışanlarının mutluluk düzeylerinin saptanması ve sosyo-demografik değişkenlerin çalışanların mutluluk düzeylerine etkilerinin incelenmesi amaçlanmıştır. Uygulama, Antalya-Manavgat'ta bulunan 11 adet 5 yıldızlı otelde çalışan 307 kişi üzerinde gerçekleştirilmiştir. Veriler Oxford Mutluluk Ölçeği-kısa formu (OHQ-SF) ve kişisel bilgi formu kullanılarak toplanmıştır. Verilerin analizinde güvenirlik analizi, faktör analizi, t-testi ve Anova analizi kullanılmıştır. Mutluluk ölçeğinin güvenilirlik değeri (Cronbach alfa) 0,711 olarak saptanmıştır. Faktör analizi sonucunda, mutluluk ölçeğinden orijinalinde olduğu gibi tek boyut elde edilmiştir. Analizler sonucunda, çalışanların mutluluk düzeyinin eğitim düzeyi, görev yapılan departman ve aylık ücret düzeyi bakımından farklılaşma gösterdiği tespit edilmiştir. Öte yandan, çalışanların mutluluk düzeyi yaş, cinsiyet, medeni durum, turizm eğitimi alıp almama, işletmede ve sektörde çalışma süreleri ile kadro durumu bakımından farklılaşma göstermemektedir. Literatürde turizm çalışanlarının mutluluğuna dair sadece birkaç araştırmaya rastlanmış olması, bu çalışmaya özgünlük katmaktadır.

Anahtar Kelimeler: Mutluluk, Otel Çalışanları, OHQ-SF, Sosyo-Demografik Değişkenler. Makale Gönderme Tarihi: 26.05.2021

Makale Kabul Tarihi: 04.09.2021

\section{Önerilen Atıf:}

Toker, B. ve Kalıpçı, M. B. (2021). Çalışanların Sosyo-Demografik Özelliklerinin Mutluluğa Etkisi: Antalya' daki Otel İşletmelerinde Bir Uygulama, Türk Turizm Araştırmaları Dergisi, 5(3): 2002-2016. (c) 2021 Türk Turizm Araştırmaları Dergisi. 


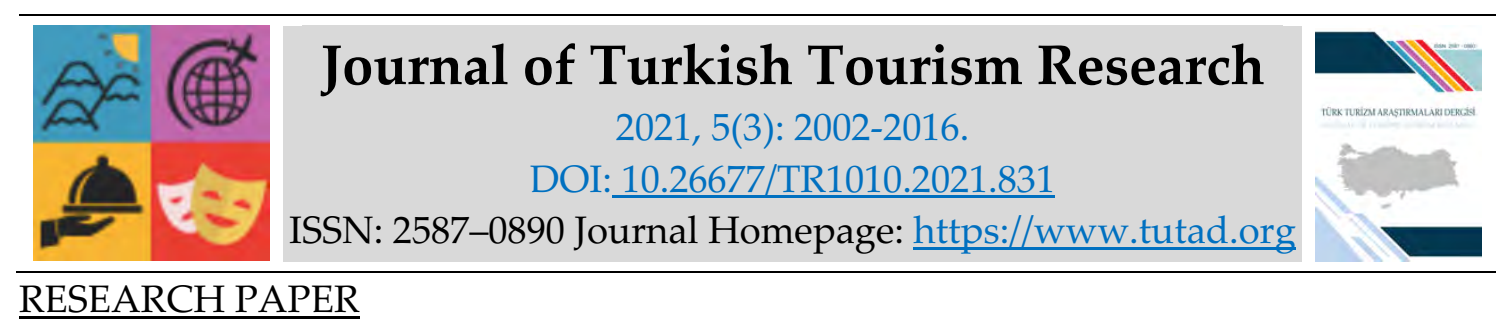

\title{
The Effect of Employees' Socio-Demographic Features on Happiness: An Application in Hotel Businesses in Antalya
}

Associate Prof. Dr. Boran TOKER, Akdeniz University, Serik Faculty of Business, Antalya, e-mail: borantoker@akdeniz.edu.tr ORCID: https://orcid.org/0000-0002-4658-1934

Dr. M. Bahadır KALIPÇI, Akdeniz University, Manavgat Vocational School, Antalya, e-mail: bkalipci@gmail.com

ORCID: https://orcid.org/0000-0001-7310-890X

\begin{abstract}
In this study, it was aimed to determine the happiness levels of tourism employees and to examine the effects of socio-demographic variables on their happiness levels. The survey was carried out on 307 persons working in 11 5-star hotels in Antalya-Manavgat. The data were collected using the Oxford Happiness Scale-short form (OHQ-SF) and a personal information form. Reliability analysis, factor analysis, t-test and Anova analysis were used in the analysis of the data. The reliability coefficient (Cronbach's alpha) of the happiness scale was found 0.711. As a result of the factor analysis, a single dimension was obtained from the happiness scale, as in the original. As a result of the analysis, it has been determined that the happiness level of the employees differs in terms of education level, the department they work in and the monthly wage level. On the other hand, the level of happiness of the employees does not differ in terms of age, gender, marital status, whether they have received tourism education or not, the duration of work in the business and the sector, and the staff status. The fact that only a few studies on the happiness of tourism employees have been encountered in the literature adds originality to this study
\end{abstract}

Keywords: Happiness, Hotel Employees, OHQ-SF, Socio-Demographic Variables.

Received: 26.05 .2021

Accepted: 04.09.2021

\section{Suggested Citation:}

Toker, B. and Kalıpçı, M. B. (2021). The Effect of Employees' Socio-Demographic Features on Happiness: An Application in Hotel Businesses in Antalya, Journal of Turkish Tourism Research, 5(3): 2002-2016.

(C) 2021 Türk Turizm Araştırmaları Dergisi. 


\section{Gíriş}

Mutlu olmak, her insanın ulaşmak istediği bir amaç olagelmiştir. Bu önemi nedeniyle de her dönemde düşünürlerin ele aldıkları konulardan biri olmuştur. Öte yandan, farklı disiplinlerdeki araştırmacılar, en karmaşık ve evrensel ölçekte tartışılan konulardan biri olan; "iyi bir yaşam arayışı ve bunun sürdürülmesi" konusu ile giderek daha fazla ilgilenmektedirler (Delle Fave vd., 2011: 186). İnsanlar mutlu olmak ister ve mutluluk insanların hayatlarında peşinde koştukları en temel amaç olarak değerlendirilebilir. Bununla birlikte, genellikle pozitif psikoloji alanı kapsamındaki çok sayıda güncel araştırmanın konusu olan mutluluğu neyin yarattığı sorusu, ideal ilişkileri, ideal grup işleyişini ve ideal toplumları yaratanların ne olduğu gibi soruları da göz önünde bulunduran gelişmekte olan bir alandır (Sheldon ve Lyubomirsky, 2007: 129).

Mutluluğun bilimsel literatürde olduğu kadar popüler söylemde de farklı anlamları bulunmaktadır. Örneğin mutluluk, genel olumlu bir ruh hali, yaşam doyumunun küresel bir değerlendirmesi, iyi bir yaşam sürmek veya insanları mutlu eden nedenler anlamına gelebilmektedir ve bağlama göre farklılık göstermektedir (Diener, 2006: 400). Ayrıca, mutluluk, düşük yoğunluklu pozitif duygular (örneğin huzur) ile yüksek yoğunluklu pozitif duyguları (sevinç, coşku) ve bunların arasındaki her şeyi kapsayan genel bir terim olarak düşünülebilir (Lyubomirsky ve Kurtz, 2008: 5). Son yıllarda, psikolojinin yanı sıra birçok disiplinde insanları neyin mutlu ettiğini anlamak için araştırmalar devam etmektedir.

$\mathrm{Bu}$ çerçevede, çalışmanın amacı konaklama işletmeleri çalışanlarının mutluluk düzeylerinin tespit edilmesi ve cinsiyet, yaş, gelir, medeni durum, eğitim düzeyi, görev yapılan departman, işletmede ve sektörde çalışma süresi ve kadro durumu gibi sosyo-demografik değişkenlerin mutluluk üzerindeki etkilerinin değerlendirilmesidir. Turizm sektörünün, yüz yüze hizmet verilen emek yoğun bir sektör olması nedeniyle, müşteri memnuniyetinde çalışan memnuniyetinin ve mutluğunun ayrı bir yeri ve önemi vardır. Çünkü, turizm sektöründeki çalışanlar mutlu olmayı ve bunun yollarını bilmiyorlarsa, müşterileri de mutlu etmeleri mümkün olamayacaktır. Bu kapsamda çalışma, turizm işletmelerinde çalışanların mutluluğu ile ilgili araştırmalara çok sınırlı sayıda rastlanmış olması sebebiyle, ilgili literatüre katkı sağlaması bakımından da ayrı bir önem taşımaktadır.

\section{LITERATÜR}

Mutluluk ve öznel iyi oluşu anlamak ve açıklamak, pozitif psikolojinin temel amacıdır. Bu bağlamda, pozitif psikoloji mutluluğu ve öznel iyi oluşu anlamak ve açıklamak yanında bunları etkileyen faktörleri de doğru bir şekilde tahmin etmeye odaklanmaktadır (Carr, 2004: 1). Mutluluk, herhangi bir anda yaşanan olumlu ruh haline ve duygulara (olumlu etki), yaşam doyumu gibi genel yaşam değerlendirmelerine veya öznel iyi oluşa atıfta bulunan popüler bir terimdir (Diener ve Ryan, 2009: 391). Pek çok filozof ve sosyal bilimci mutluluk ya da öznel iyi oluşu tanımlamaya çalışmıştır, fakat literatürde araştırmacıların üzerinde uzlaştığı net bir tanımı bulunmamaktadır. Tanımlar, literatürde genellikle üstü kapalı olarak yapılmaktadır ve kullanılan ölçekler aracılı̆̆ıyla da ima edilmektedir (Kangal, 2013: 217). Bu konudaki araştırmalarıyla tanınan ve Bay Mutluluk (Mr. Happiness) olarak da bilinen Diener'e (2000: 34) göre mutluluk ya da öznel iyi oluş; insanların yaşamları hakkındaki değerlendirmeleri hem duygusal hem de bilişsel değerlendirmeleri ifade etmektedir. Yine mutlulukla ilgili öncü çalışmalarıyla bilinen Veenhoven'e (1997: 5) göre mutluluk, bir kişinin bütün olarak mevcut yaşamının genel kalitesini olumlu olarak değerlendirme derecesidir. Başka bir ifadeyle, kişinin sürdürdüğü hayatını ne kadar sevdiğidir. Lyubomirsky, Sheldon ve Schkade (2005: 115) ise mutluluğu sık görülen olumlu etki, yüksek yaşam memnuniyeti ve nadiren olumsuz etki olarak 
tanımlamaktadır. Sonuçta, kişilerin genel olarak, sevinç, neşe, güven, umut gibi olumlu duyguları sık hissetmesi; kaygı, nefret, öfke, korku, umutsuzluk, üzüntü gibi olumsuz duyguları da görece daha az hissetmesi ve sağlık, iş, evlilik gibi yaşam alanlarından tatmin olması mutluluğun temel göstergeleri olarak ifade edilmektedir (Doğan ve Sapmaz, 2012: 298).

Öte yandan, mutluluğun veya öznel iyi oluşun belirleyicilerini tanımlamak için birçok araştırma yapılmıştır. Bu çerçevede, iyi oluşun demografik değişkenler (örneğin; Diener, 1984; Diener ve Diener, 1995; Diener vd., 1999; Myers, 2000), kişilik özellikleri ve tutumlar (örneğin; Diener ve Lucas, 1999) ve hedeflerin özellikleri (örneğin; McGregor ve Little, 1998) dahil olmak üzere çok çeşitli faktörlerle ilişkili olduğu görülmüştür (Lyubomirsky vd., 2005). Ayrıca, çeşitli çalışmalar mutlu kişilerin evlilik, ilişkiler, gelir, sağlık, uzun ömür ve iş performansı dahil olmak üzere birçok yaşam alanında başarılı olduklarını göstermektedir. Bu kişilerin daha yaratıcı, çoklu ve sıkıcı görevleri üstlenebilen, daha güvenilir, yardımcı ve sosyal oldukları görülmüştür (Lyubomirsky, King ve Diener, 2005: 846; David, Boniwell ve Ayers, 2013).

Mutluluk konusundaki çalışmalarıyla tanınan diğer bir araştırmacı olan Lyubomirsky ve arkadaşları (2005: 116) konuyla ilgili yapılmış araştırmaları göz önünde bulundurarak mutluluğu belirleyen faktörlerin üç gruptan oluştuğunu ifade etmiştir. Bunlardan ilki genetik faktörlerdir ve mutluluğu \%50 oranında etkilemektedir. İkincisi amaçlı faaliyetler olup; mutluluğa etkisi \%40 düzeyindedir. Son olarak çeşitli demografik/durumsal değişkenlerin mutluluğu etkisi ise \%10 oranındadır.

Bu demografik değişkenlerden biri olan cinsiyet ile mutluluk arasındaki ilişkileri ele alan 93 araştırmayı inceleyen Wood, Rhodes ve Whelan (1989) ve 1981-1999 yılları arasında 65 toplumdan 146.000 kişilik örneklemi içeren Dünya Değerler Araştırması verilerini kullanan Inglehart (2002) kadınların erkeklerden daha fazla mutluluk ve yaşam doyumuna sahip olduğunu ifade etmektedirler. Graham ve Chattopadhyay da (2013) 2005 yılından itibaren 160 ülkeden elde edilen Gallup Dünya Anketindeki verilere dayanan ekonometrik çalışmasında dünya genelinde birkaç düşük gelirli ülke haricinde kadınların erkeklerden daha yüksek mutluluk düzeylerine sahip olduğunu tespit etmiştir. Öte yandan, Haring, Stock ve Okun (1984) ise meta-analitik tekniklerle mevcut ampirik literatürdeki bulguları değerlendirerek erkeklerin kadınlardan biraz daha yüksek mutluluğa sahip olduğunu ve cinsiyetin mutluluğun istatistiksel olarak anlamlı bir yordayıcısı olmasına rağmen, çok az varyansı açıkladığını ortaya koymuştur. Bununla birlikte, bazı araştırmalarda da erkek ve kadınların mutluluk düzeylerinin ya çok fazla farklılık göstermediği ya da tutarsız sonuçlar ortaya çıtığı da görülmektedir (Örneğin; Shmotkin, 1990; Veenhoven, 1997; Diener vd., 1999; Diener ve Ryan, 2009; Batz ve Tay, 2017; BatzBarbarich vd., 2018).

Birçok çalışma, mutluluk ile yaş ilişkisinin U şeklinde olduğunu ve yaklaşık 40 ila 50 yaşları arasında minimum düzeyde bulunduğunu ortaya koymuştur (Laaksonen, 2018). Beja (2018) 1995-2014 dönemi için dünyadaki ortalama nüfusun yaklaşı \%90'ını temsil eden ve 42'si üst, 46'sı orta ve 7'si düşük gelirli toplam 95 ekonomiden 240.699 gözlem içeren Dünya Değerler Araştırması veri setini kullanarak mutluluk ve yaş arasındaki U şeklindeki ilişkiyi test etmiş ve doğrulamıştır. Bir başka ifade ile, mutluluk genç yetişkinlikte yüksek bir noktada azalır, orta yaşta düşük bir noktaya ulaşır ve daha sonra yaşlılıkta başka bir yüksek noktaya ulaşmak için artar. Sonuçlar, yaşlılıkta mutluluğun yüksek noktasının genç erişkinlikte mutluluğun yüksek noktasından daha düşük olduğunu göstermektedir. Veenhoven (1997) ise yaşlı ve gençlerin çoğu ülkede eşit derecede mutlu olduğunu ifade etmektedir. Öte yandan, Frijters ve Beatton (2012) psikologların çoğunun yaş ile mutluluk arasında hiçbir ilişkinin olmadığı sonucuna vardığını, fakat iktisat literatürünün orta yaşta meydana gelen minimum memnuniyet düzeyi ile olası bir U şeklinde ilişki olduğunu ortaya çıkardığını belirtmektedir. 
Stack ve Eshleman (1998) 17 ulustan oluşan araştırmalarında, medeni durum ile mutluluk arasındaki ilişkinin 17 ulusun 16'sında geçerli olduğunu ve ilişkinin gücünün 17 ülkenin 14'ünde önemli ölçüde değişmediğini belirlemişlerdir. Ayrıca evliliğin, erkekler ve kadınlar arasında eşit derecede mutluluk artırdığını da saptamışlardır. Diener vd., (2000) ise 42 ülkeden 59.169 kişilik bir örneklemde, kültürel değişkenlerin etkilerinin küçük olması nedeniyle medeni durum ile mutluluk arasındaki ilişkilerin dünya genelinde çok benzer olduğu sonucuna ulaşmışlardır. Öte yandan, Haring-Hidore vd., (1985) meta-analitik teknikler kullanarak, evli olma ve mutluluk arasındaki ilişki üzerine 58 ampirik kaynaktan elde edilen sonuçları değerlendirmiş ve evli olmanın mutluluk ile pozitif ilişkili olduğunu saptamıştır. Ancak bu ilişkinin büyüklüğü beklenenden daha zayıf bulunmuştur.

Genel olarak, gelir ve mutluluk ilişkisine dair yapılan araştırmalar incelendiğinde, gelir arttıkça mutluluğun olumlu, ancak azalan bir etkiye sahip olduğu görülmektedir. Artan gelir, yoksulluk düzeyinde veya az gelişmiş ülkelerde yaşayanların mutluluğunu önemli ölçüde etkilerken; zenginlik ve yaşam memnuniyeti arasındaki bağlantının gücü, daha yüksek gelir düzeylerinde azalmaktadır (Diener ve Ryan, 2009; Diener, Ng ve Tov, 2008). Ball ve Chernova (2008) Dünya Değerler Anketinden elde edilen verileri kullanarak hem mutlak hem de göreceli gelirin olumlu ve önemli ölçüde mutlulukla ilişkili olduğunu, bununla birlikte nicel olarak göreli gelirdeki değişikliklerin mutluluk üzerinde mutlak gelirdeki değişikliklerden çok daha büyük etkilerinin olduğunu saptamışlardır. Diener vd., (1999) de çalışmalarında, varlıklı insanların, zengin ülkelerdeki fakir insanlardan sadece biraz daha mutluyken, zengin ülkelerin ise fakir ülkelerden çok daha mutlu olduğu sonucuna ulaşmışlardır. Benzer şekilde, Diener (1984) daha zengin olan insanların daha mutlu olma eğiliminde olduğunu; ancak genel gelir seviyesi arttıkça, mutluluğun bununla birlikte mutlaka artmadığını ifade etmektedir. Diener (1984) bunun sebeplerine ilişkin bazı varsayımlar ileri sürmüştür: İlk olarak, gelirin yalnızca aşırı yoksulluk seviyelerinde etkisi vardır, ancak temel ihtiyaçlar karşılandığında ise gelir artık etkili olmamaktadır. İkinci olarak, gelirle birlikte değişen statü ve güç gibi faktörler, gelirin mutluluk üzerindeki etkisinde sorumlu olabilir. Bununla birlikte, bunlar bir toplum içinde görecelidir ve bu nedenle gerçek gelir arttıkça artmaz. Üçüncü bir varsayım ise gelirin etkisinin doğrudan ancak, sosyal karşılaştırmaya bağlı olduğudur. İnsanlar, kendi durumlarını başkalarıyla karşılaştırarak ne kadar tatmin olmaları gerektiğine karar vermektedirler. Özetle, para ve mutluluk örtüşmez; daha ziyade para nihai amaç için sadece bir araçtır (Sherman vd., 2021:1067).

Ampirik araştırmalar, eğitimin bölgesel ve dünya ölçeğinde mutluluk üzerinde olumlu bir etkisi olduğunu ortaya koymuştur (Castriota, 2006). 556 çalışmanın meta analizini gerçekleştiren Witter vd. (1984) de eğitimin, öznel iyi oluşla önemli ölçüde pozitif ilişkisi olduğunu ve varyansın \%1 ila 3'ünü açıkladığını ifade etmişlerdir. Öte yandan, eğitim ve öznel iyi oluş arasındaki ilişkinin en azından bir kısmının, eğitimin gelir ve mesleki durumla birlikte değişmesinden kaynaklandığını ortaya koyan çalışmalar mevcuttur (Diener vd., 1999).

\section{YÖNTEM}

\section{Araştırmanın Hipotezleri}

Çalışmada ilgili literatürün değerlendirilmesi sonucunda oluşturulan hipotezler aşağıda yer almaktadır:

$\mathrm{H}_{1}$ : Otel çalışanlarının mutluluk düzeyleri cinsiyetlerine göre farklılık göstermektedir.

$\mathrm{H}_{2}$ : Otel çalışanlarının mutluluk düzeyleri yaşlarına göre farklılık göstermektedir.

$\mathrm{H}_{3}$ : Otel çalışanlarının mutluluk düzeyleri medeni durumlarına göre farklılık göstermektedir. 
H4: Otel çalışanlarının mutluluk düzeyleri aylık kazançlarına göre farklılık göstermektedir.

H5: Otel çalışanlarının mutluluk düzeyleri eğitim düzeylerine göre farklılık göstermektedir.

$\mathrm{H}_{6}$ : Otel çalışanlarının mutluluk düzeyleri eğitimlerinin turizmle ilgisine göre farklılık göstermektedir.

$\mathrm{H}$ : Otel çalışanlarının mutluluk düzeyleri çalıştıkları departmanlara göre farklılık göstermektedir.

Hs: Otel çalışanlarının mutluluk düzeyleri işletmede çalışma sürelerine göre farklılık göstermektedir.

H9: Otel çalışanlarının mutluluk düzeyleri sektörde çalışma sürelerine göre farklılık göstermektedir.

H10: Otel çalışanlarının mutluluk düzeyleri kadro durumlarına göre farklılık göstermektedir.

\section{Ölçüm Aracı ve Örneklem}

Çalışmada temel veri toplama aracı olarak anket kullanılmıştır. Anketin ilk bölümünde otel çalışanlarının sosyo-demografik özelliklerini belirlemeye yönelik sorular yer almaktadır. İkinci bölümde ise mutluluk ölçümü için Oxford Mutluluk Ölçeği-kısa formu kullanılmıştır. Oxford Mutluluk Ölçeği-kısa formu, Hills ve Argyle (2002) tarafından geliştirilen ve mutluluk düzeyini saptamak için kullanılan 8 maddelik bir ölçektir. Hills ve Argyle (2002) ölçeğin güvenirlik değerini (Cronbach alfa) 0,91 olarak tespit etmişlerdir. Bu ölçeğin Türkçe uyarlaması ise Doğan ve Akıncı Çötok (2011) tarafından gerçekleştirilmiş ve psikometrik özellikleri değerlendirilmiştir. Doğan ve Akıncı Çötok (2011) çalışmalarındaki faktör analizi sonucunda ölçeğin 7 maddelik tek faktörlü bir yapıya sahip olduğunu saptamışlar ve ölçeğin güvenirlik değerini (Cronbach alfa) 0,74 olarak tespit etmişlerdir. Ölçekte beşli Likert derecelendirmesi (1- Kesinlikle Katılmıyorum, 5- Kesinlikle Katıliyorum) kullanılmıştır.

Araştırmanın örneklemini Manavgat bölgesinde bulunan işletme ve yatırım belgeli konaklama tesislerinin çalışanları oluşturmaktadır. Örneklem olarak Manavgat'ın seçilme nedeni hem Türkiye'de hem de Antalya'da en fazla turistin ziyaret ettiği merkezlerden biri olmasının yanı sıra, çalışmada daha verimli sonuçların sağlanabileceği yıl boyunca faaliyet gösteren otellerin de bu bölgede yer almasıdır. Bununla birlikte, tüm yıl açık olan otellerde çalışanların tam sayısı bilinemediği için kolayda örnekleme yöntemi tercih edilmiştir. Manavgat bölgesinde tüm yıl açık olan 5 yıldızlı otellerden çalışmaya katılmayı kabul eden 11 tanesine ulaşılmıştır. Bu otellerin yönetimleri ile görüşülmüş ve izin alınmak suretiyle, 1 Kasım 2019 ile 25 Aralık 2019 tarihleri arasında toplam 340 adet anket toplanmıştır. Bu anketlerden eksik veri bulunan 33 anket değerlendirme dışı bırakılmış ve kalan 307 anketin kullanılabilir olduğu tespit edilmiştir.

\section{Verilerin Analizi}

Otel çalışanlarının vermiş oldukları cevaplar doğrultusunda elde edilen veriler SPSS 23.0 istatistik paket programı ile analiz edilmiştir. İstatistiksel anlamda veriler tanımlayıcı ve çıkarımsal istatistik kapsamında değerlendirilmiştir. Bu çerçevede, ilk olarak sosyo-demografik soruların frekans dağılımları incelenmiştir. Sonrasında mutluluk ölçeğinin güvenilirliği (Cronbach alfa) test edilmiştir. Ardından ölçeğe açımlayıcı faktör analizi (principal component 
analysis) yapılmıştır. Daha sonra ise araştırma hipotezlerini test etmek amacıyla t testi ve Anova analizlerinden faydalanılmıştır.

\section{BULGULAR}

Tanımlayıcı istatistik çerçevesinde elde edilen sosyo-demografik veriler Tablo 1'de yer almaktadır. Çalışanların \%61,2'si erkek, \%38,8'i ise kadındır. Çalışanların yaşlarının dağılımına bakıldığında; \%20,5'i 18-25, \%49,1'i 26-35 ve geri kalan \%30,4'ü 36 ve üzeri yaş aralığındadır. Çalışanların \%62,2'si evli, \%37,8'i bekardır. Çalışanların aylık kazançları ile ilgili sonuçlara bakıldığında; \%25,7'si 2020 TL'ye kadar, \%52,8'i 2021-3000 TL arası, \%21,5'i de 3001 TL ve üzeri geliri olduğu görülmektedir. Çalışanların \%30'u ilköğretim, \%43'ü lise ve \%27'si lisans ve lisansüstü eğitimini tamamlamıştır. Bu çalışanların \%36,8'i turizm eğitimi almışken, \%63,2'si ise turizm eğitimi almamıştır. Çalışanların \%9,4'ü ön büro, \%19,5'i yiyecek ve içecek, \%10,1'i mutfak, $\% 20,2^{\prime}$ si kat hizmetleri, \%8,5'i muhasebe, \%6,5'i teknik servis, $\% 7,5^{\prime}$ i güvenlik ve $\% 18,2$ 'si diğer (kalite, animasyon, halkla ilişkiler, bilgi işlem) bölümlerinde çalışmaktadırlar. Çalışanların otellerinde çalışma sürelerine bakıldığında \%73,2' si 1-3 yıl arasında, \%26,8' i 4 yıldan fazla süredir bulundukları otelde çalışmaktadır. Sektörde çalışma süresine bakıldığında ise \%58,9'u 1-9 yıl arasında, \%41,1'i 10 yıldan uzun süredir sektörde çalışmaktadır. Öte yandan, çalışanların kadro durumu incelendiğinde, \%73'ünün tam zamanlı çalışırken, \%27'sinin sezonluk çalışmakta olduğu görülmüştür.

Tablo 1. Katılımcların Sosyo-Demografik Profili

\begin{tabular}{|c|c|c|c|}
\hline & & Say1 & $\%$ \\
\hline \multirow[t]{2}{*}{ Cinsiyet } & Erkek & 188 & 61,2 \\
\hline & Kadın & 119 & 38,8 \\
\hline \multirow{3}{*}{ Yaş } & $18-25$ & 63 & 20,5 \\
\hline & $26-35$ & 126 & 49,1 \\
\hline & 36 ve üzeri & 118 & 30,4 \\
\hline \multirow[t]{2}{*}{ Medeni Durum } & Evli & 191 & 62,2 \\
\hline & Bekar & 116 & 37,8 \\
\hline \multirow{3}{*}{$\begin{array}{l}\text { Aylık Kazanç Miktarı } \\
\text { (TL) }\end{array}$} & $2020^{\prime}$ ye kadar & 79 & 25,7 \\
\hline & $2021-3000$ & 162 & 52,8 \\
\hline & 3001 ve üzeri & 66 & 21,5 \\
\hline \multirow{3}{*}{ Eğitim Düzeyi } & İlköğretim & 92 & 30,0 \\
\hline & Lise & 132 & 43,0 \\
\hline & Lisans ve lisansüstü & 83 & 27,0 \\
\hline \multirow[t]{2}{*}{ Turizm Eğitimi Durumu } & Evet & 113 & 36,8 \\
\hline & Hayır & 194 & 63,2 \\
\hline \multirow{8}{*}{ Departman } & Ön büro & 29 & 9,4 \\
\hline & Yiyecek-İçecek & 60 & 19,5 \\
\hline & Mutfak & 31 & 10,1 \\
\hline & Kat Hizmetleri & 62 & 20,2 \\
\hline & Muhasebe & 26 & 8,5 \\
\hline & Teknik Servis & 20 & 6,5 \\
\hline & Güvenlik & 23 & 7,5 \\
\hline & $\begin{array}{l}\text { Diğer (kalite, animasyon, halkla ilişkiler, } \\
\text { bilgi işlem) }\end{array}$ & 56 & 18,2 \\
\hline \multirow[t]{2}{*}{ İşletmede Çalışma Süresi } & $1-3$ yıl & 225 & 73,2 \\
\hline & 4 yildan fazla & 82 & 26,8 \\
\hline \multirow[t]{2}{*}{ Sektörde Çalışma Süresi } & $1-9$ y1l & 181 & 58,9 \\
\hline & 10 yıldan fazla & 126 & 41,1 \\
\hline \multirow[t]{2}{*}{ Kadro Durumu } & Tam Zamanlı & 224 & 73,0 \\
\hline & Sezonluk & 83 & 27,0 \\
\hline
\end{tabular}


Çalışmada, çkarımsal istatistik kapsamında ilk olarak verilere güvenilirlik analizi yapılmıştır. Bu çerçevede, ölçeğin güvenilirlik değeri (Cronbach alfa katsayısı) 0,711 olarak saptanmıştır. Elde edilen bu güvenilirlik değerine göre, değişkenleri daha sağlıklı şekilde saptamak ve ölçeğin yapı geçerliliğini test etmek için mutluluk ölçeğine faktör analizi yapılmıştır. Faktör analizi sonucunda, 7 sorunun Barlett küresellik testi sonuçları $(0,21$ ve sig. $p<0,001)$ ve Kaiser-MeyerOlkin örneklem değeri $(, 779)$ kabul edilebilir sınırlar içinde olduğu anlaşılmıştır. Ölçeğe uygulanan temel bileşenler analizi için varimax faktör döndürme seçeneği kullanılmış olup, elde edilen saçılma diyagramına göre özdeğerleri 1'in $(>1)$ üzerinde olan veriler değerlendirmeye alınmış ve ölçeğin orijinalindeki gibi tek boyut elde edilmiştir. Faktör analizi sonuçları Tablo 2' de yer almaktadır.

Tablo 2. Faktör Analizi Sonuçları

\begin{tabular}{|l|l|l|l|}
\hline & $\begin{array}{l}\text { Faktör } \\
\text { Yükleri }\end{array}$ & Özdeğer & $\begin{array}{l}\text { Açıklanan } \\
\text { Varyans } \\
\text { Yüzdesi }\end{array}$ \\
\hline Faktörler & & 3,197 & 45,666 \\
\hline 4. Çevremdeki güzelliklerin farkına varırım & 0.872 & & \\
\hline 3. Hayatımdaki her şeyden oldukça memnunum & 0.867 & & \\
\hline 7. Geçmişle ilgili mutlu anılara sahip değilim & 0.865 & & \\
\hline 1. Kendimden hoşnut değilim & 0.861 & & \\
\hline 5. Yapmak istediğim her şeye zaman bulabilirim & 0.838 & & \\
\hline $\begin{array}{l}\text { 6. Zihinsel olarak kendimi tamamen zinde (dinç) } \\
\text { hissederim }\end{array}$ & 0.711 & & \\
\hline 2. Hayatın çok ödüllendirici olduğunu hissediyorum & 0.685 & & \\
\hline
\end{tabular}

Çalışanların sosyo-demografik özellikleri ile mutluluk düzeyleri arasındaki farklılıkları ölçmek için oluşturulan hipotezler $\mathrm{t}$ testi ve Anova analizleri aracılığıyla test edilmiştir.

Anova testi sonucuna göre, otel çalışanlarının mutluluk düzeyi eğitim seviyesi açısından farklılaşmaktadır $(F=5,712 ; p<0,05)$. Farklılı̆̆ın hangi eğitim düzeyleri arasında olduğunu tespit etmek için yapılan çoklu karşılaştırma testlerinden Tukey testi sonuçlarına göre; lisans mezunu otel çalışanlarının mutluluk düzeyinin (Ort:3,85; SS:0,6856), lise mezunu çalışanlara (Ort:3,52; SS:0,7899) göre daha yüksek olduğu görülmüştür. Sonuç olarak, $\mathrm{H}_{5}$ hipotezi kabul edilmiştir.

Anova testi sonucuna göre, otel çalışanlarının mutluluk düzeyi görev aldıkları departmanlar açısından farklılaşmaktadır $(\mathrm{F}=2,543 ; \mathrm{p}<0,05)$. Farklılığın hangi departmanlar arasında olduğunu tespit etmek için yapılan çoklu karşılaştırma testlerinden Tukey testi sonuçlarına göre; ön büro departmanı çalışanlarının mutluluk düzeyinin (Ort:4,03; SS:0,5205), teknik servis departmanı çalışanlarına (Ort:2,94; SS:0,7857) göre daha yüksek olduğu görülmüştür. Sonuç olarak, H7 hipotezi kabul edilmiştir.

Anova testi sonucuna göre, otel çalışanlarının mutluluk düzeyi, aylık kazançları açısından farklılaşmaktadır ( $F=7,072 ; p<0,05)$. Farklılığın hangi kazanç düzeyleri arasında olduğunu tespit etmek için yapılan çoklu karşılaştırma testlerinden Tukey testi sonuçlarına göre; 2021-3000 TL kazanan çalışanların mutluluk düzeyinin (Ort:3,82; SS:0,6693), 2020 TL'ye kadar kazancı olanlar (Ort:3,56; SS:0,8224) ve 3001 TL ve üzeri kazanan çalışanlara (Ort:3,46; SS:0,7309) göre daha yüksek olduğu görülmüştür. Sonuç olarak, $\mathrm{H}_{4}$ hipotezi kabul edilmiştir. 
Öte yandan Anova testi sonucuna göre, çalışanların mutluluk düzeyleri yaşları açısından anlamlı düzeyde farklılaşmamaktadır. Bu nedenle; $\mathrm{H}_{2}$ hipotezi reddedilmiştir. Anova testlerinin sonuçları Tablo 3'te yer almaktadir.

Tablo 3. Anova Testi Sonuçları

\begin{tabular}{|l|l|l|l|}
\hline Değişken & Df & F & Sig. \\
\hline Eğitim & 4 & 5,712 &, 004 \\
\hline Departman & 7 & 2,543 &, 000 \\
\hline Ücret & 2 & 7,072 &, 001 \\
\hline Yaş & 2 & 1,929 &, 147 \\
\hline
\end{tabular}

T-testi sonuçlarına göre, çalışanların mutluluk düzeyleri; cinsiyet değişkeni $(\mathrm{t}=-0,561 ; \mathrm{p}>0,05)$, medeni durum değişkeni ( $t=-, 004 ; p>0,05)$, turizm eğitimi değişkeni $(t=1,066 ; p>0,05)$, işletmede çalışma süresi değişkeni $(t=1,221 ; p>0,05)$, sektörde çalışma süresi değişkeni $(t=0,723 ; p>0,05)$ ve kadro durumu değişkeni ( $\mathrm{t}=1,086 ; \mathrm{p}>0,05)$ açısından farklılaşmamaktadır. Bu sonuçlara göre; $\mathrm{H}_{1}$, $\mathrm{H}_{3}, \mathrm{H}_{6}, \mathrm{H}_{8}, \mathrm{H}_{9}$ ve $\mathrm{H}_{10}$ hipotezleri reddedilmiştir. T-testi sonuçları Tablo 4'te verilmiştir.

Tablo 4. T-Testi Sonuçları

\begin{tabular}{|l|l|l|l|}
\hline Değişken & Df & T & Sig. \\
\hline Cinsiyet & 305 &,- 561 &, 575 \\
\hline Turizm Eğitimi & 305 & 1,066 &, 287 \\
\hline Medeni Durum & 305 &,- 004 &, 997 \\
\hline Kadro Durumu & 305 & 1,086 &, 278 \\
\hline İşletmede Çalışma Süresi & 305 & 1,221 &, 223 \\
\hline Sektörde Çalışma Süresi & 305 &, 723 &, 374 \\
\hline
\end{tabular}

\section{SONUÇ ve TARTIŞMA}

$\mathrm{Bu}$ çalışmanın amacl, konaklama işletmelerinde çalışanların mutluluk düzeylerinin tespit edilmesi ve cinsiyet, yaş, gelir, medeni durum, eğitim düzeyi, görev yapılan departman, işletmede ve sektörde çalışma süresi ve kadro durumu gibi sosyo-demografik değişkenlerin mutluluk üzerindeki etkilerinin incelenmesidir. Uygulama, Türkiye'nin ve Antalya'nın en fazla turist çeken bölgelerinden biri olmasının yanında daha sağlıklı sonuçların elde edilebileceği tüm yıl faaliyet gösteren otellerin çoğunlukta olduğu Manavgat'taki beş yıldızlı otel çalışanları üzerinde gerçekleştirilmiştir. Otel çalışanlarının mutluluk düzeyleri Oxford Mutluluk ÖlçeğiKısa Formu kullanılarak ölçülmüştür. Çalışanların 3,68 (SS:0,7388) ortalama ile ortanın biraz üzerinde bir mutluluk düzeyine sahip oldukları görülmüştür.

Literatürde turizm çalışanlarının mutluluğu ile ilgili sınırlı sayıda çalışmaya rastlanmış olup; elde edilen bulgular, bu çalışmaların bulguları ile karşılaştıııldığında benzer mutluluk puanlarıyla karşılaşılmıştır. Bu kapsamda, Yurcu ve Atay (2015) da Oxford Mutluluk Ölçeği-kısa formunu kullanarak, Antalya Serik ilçesindeki Belek\Kadriye bölgesinde bulunan 5 yıldızlı 50 oteldeki 2.051 çalışanın mutluluğunu etkileyen demografik değişkenleri inceledikleri çalışmalarında, katılımcıların çoğunlukla 3 ve 4 seçeneklerinde yoğunlaştıklarını ifade etmişlerdir. Ayrıca, elde ettikleri sonuçların, katılımcıların uç değerlerde olmadığını ve ne çok iyi ne de çok kötü olduklarını; genel olarak iyi olduklarını gösterdiğini belirtmişlerdir. Sürücü (2016) ise otel 
işletmelerindeki çalışanların iyimserlik, yaşam tatmini ve mutluluk seviyelerini saptayarak, bu değişkenler arasındaki ilişkiyi incelemek amacıyla, Antalya'daki 5 yıldızlı otellerde çalışan 397 kişi üzerinde bir uygulama gerçekleştirmiştir. Bu uygulamada da otel çalışanlarının mutluluk düzeyi Oxford Mutluluk Ölçeği kullanılarak ölçülmüş ve katılımcıların mutluluk düzeyini belirlemeye dönük ifadelerin genel olarak orta düzeyin üzerinde olduğu belirtilmiştir. Işık, Çetinkaya ve Işık (2017) Erzurum'daki Palandöken Kış Turizm merkezinde faaliyet gösteren konaklama işletmelerinde görev yapan kadın çalışanların mutluluk seviyelerini saptamak; mutluluk ve iş doyumu arasındaki ilişkiyi ve mutluluğun iş doyumu üzerindeki etkilerini tespit etmek amacıyla 127 kişi üzerinde bir çalışma gerçekleştirmişlerdir. Binboğa (2019) ise AydınKuşadası'nda görev yapan 360 turist rehberi üzerinde gerçekleştirdiği çalışmada, duygusal emek ve öznel iyi oluş arasındaki ilişkiyi ve demografik değişkenlerin etkilerini incelemiştir. Bu çalışmada da rehberlerin mutluluk düzeylerini ölçmek için Oxford Mutluluk Ölçeği kullanılmış ve gerçekleştirilen analiz sonuçlarına göre katılımcıların genelinin mutlu olduğu ifade edilmiştir.

Çalışmada, otel çalışanlarının mutluluk düzeyinin eğitim düzeyi, görev yapılan departman ve aylık ücret düzeyi bakımından farklılaşma gösterdiği saptanmıştır. Otel çalışanlarından lisans mezunu olanların mutluluk düzeylerinin, lise mezunu olan çalışanlara göre daha yüksek olduğu tespit edilmiştir. Böylece, eğitim seviyesindeki artışın çalışanların mutluluğu üzerinde olumlu bir etkiye sahip olduğu görülmektedir. Yurcu ve Atay (2015) ise otel çalışanlarının mutluluk düzeylerinin eğitim durumu değişkenine göre anlamlı bir farklılaşma gösterdiğini; ilköğretim ve doktora eğitimi almış olanların mutluluk düzeylerinin daha yüksek, lisans eğitimi almış olanların mutluluk düzeylerinin ise daha düşük olduğunu belirtilmektedir. Binboğa (2019) da rehberlerin mutluluk düzeyleri ile eğitim seviyeleri arasında anlamlı farklılık olduğunu ifade etmektedir. Bu kapsamda, lisansüstü eğitim seviyesine sahip olan katılımcıların mutluluk düzeyleri diğer eğitim gruplarına göre yüksek olduğunu ifade etmiştir.

Ön büro departmanında görev yapan otel çalışanlarının mutluluk düzeyinin, teknik servis departmanında çalışanlara göre daha yüksek olduğu tespit edilmiştir. Operasyonel bir bölüm olan önbüro müşterilerle sürekli olarak etkileşim halindedir ve bu bölüm otelin vitrini olarak da tanımlanabilir. Dolayısıyla, konuklarla sürekli yüz yüze etkileşimde olan bu bölüm çalışanları müşteri memnuniyeti ve mutluluğunda önemli bir yere sahiptir. $\mathrm{Bu}$ nedenle, hizmetin sunulmasında diğer operasyonel bölümler gibi hem üst yönetimden daha çok takdir gören hem de daha çok ücret ve bahşiş alan önbüro çalışanlarının, teknik servis gibi geri planda kalan yardımcı bölümlerde çalışanlardan daha yüksek düzeyde mutluluğa sahip olması doğaldır.

Ayda 2021-3000 TL ücret alan otel çalışanlarının mutluluk düzeylerinin, 2020 TL'ye kadar ücret alanlar ve 3001 TL ve üzeri ücret alan çalışanlara göre daha yüksek olduğu saptanmıştır. Yurcu ve Atay (2015) ise benzer şekilde otel çalışanlarında mutluluk düzeyinin gelir durumu değişkenine göre anlamlı bir farklılaşma olduğunu; 500 TL ve altı, 1001-1500 TL, 1501-2000 TL gelir aralığında yer alan çalışanların mutluluk düzeylerinin daha yüksek, 500-1000 TL ve $2001 \mathrm{TL}$ ve üzeri gelir aralığındaki çalışanların mutluluk düzeylerinin ise daha düşük olduğunu ifade etmektedirler. Binboğa (2019) da rehberlerin mutluluk düzeyi ile gelir seviyesi arasında anlamlı farklılık saptamıştır ve 1000 TL ve altı gelir seviyesine sahip olan bireylerin mutluluk düzeyinin diğer gelir gruplarına göre yüksek olduğunu belirtmiştir.

Otel çalışanlarının mutluluk düzeylerinin; yaşları, cinsiyetleri, medeni durumları, turizm eğitimi alıp almamaları, işletmede ve sektörde çalışma süreleri ile kadro durumları bakımından farklılaşmadığı saptanmıştır. Yurcu ve Atay (2015) de benzer şekilde, otel çalışanlarının mutluluk düzeylerinin yaş, medeni durum ve kadro durumu değişkenlerine göre anlamlı bir farklılaşma göstermediğini belirtmektedir. Farklı olarak, aynı çalışmada katılımcıların mutluluk düzeyleri ile cinsiyet değişkeni arasında anlamlı bir farklılaşma olduğu ve erkeklerin mutluluk düzeylerinin 
kadınlardan daha yüksek olduğu ifade edilmektedir. Yine aynı çalışmada, otel çalışanlarının mutluluk düzeylerinin meslek yılı değişkenine göre anlamlı bir farklılaşma gösterdiği ve 26 ve üzeri meslek yılına sahip çalışanların mutluluk düzeylerinin daha yüksek, 1-5 arası meslek yılına sahip çalışanların mutluluk düzeylerinin ise daha düşük olduğu belirtilmiştir. Binboğa (2019) da çalışmasında benzer biçimde, katılımcıların cinsiyetleri ve medeni durumları ile mutluluk düzeyleri arasında anlamlı farklılık bulamamıştır. Öte yandan aynı çalışmada, katılımcıların mutluluk düzeyleri ile yaş grupları ve çalışma süreleri arasında anlamlı farklılıklar tespit etmiştir. Bu kapsamda, 18-25 ve 36-45 yaş grubunun mutluluk düzeylerinin, diğer yaş gruplarına göre daha yüksek olduğunu belirtmiştir. Bunun yanında yine aynı çalışmada, 6-10 yıl arasında çalışanların mutluluk düzeylerinin diğerlerine göre daha yüksek olduğu da ifade edilmiştir.

Sağlıklı ve mutlu çalışanlar, uzun vadede daha üretken olma, müşterileri ve etkileşimde bulundukları, iş yaptıkları kişiler için daha iyi mal ve hizmet üretme eğilimindedirler. Bugün, insanların hayatlarında genel mutluluğu bulmaları için bir umutları varsa, işlerinde de mutlu olmaları gerektiği açıktır. Tek başına, çalışmak, elbette bir kişiyi mutlu edemez; ancak kişi işinde mutsuzsa gerçekten mutluda olamaz (Gavin ve Mason, 2004:381). Bununla birlikte, daha mutlu bireyler iş hayatında daha başarılıdırlar ve mutsuz bireylere göre daha kolay iş bulur ve kariyerlerinde daha hizlı ilerleme gösterirler (Frey ve Stutzer, 2002:13). Öte yandan yöneticiler, performansın önde gelen göstergeleri olarak iyi oluş ve mutluluğa yönelik yeni bir bakış açısına sahipken, günümüzün çalışan mutluluğu daha yüksek düzeyde üretkenlik ile ilişkilidir (Niyazieva ve Zhechev, 2020:353). Bu kapsamda mutluluk deneyimi, işyerinde üretkenliği, yaratıcılığı ve işbirliğini teşvik ettiği için işyeri başarısı açısından da faydalıdır (De Neve vd., 2013:61).

İşletme yönetiminin performans değerlendirmeleri için gösterdiği çabanın yanı sıra, çalışanların mutlu olabileceği ortamlar yaratmak için de çaba harcaması gerekmektedir. Çünkü mutlu iş ortamları yaratmak, insanları mutlu etmenin ve başarılı sonuçlar almanın ön koşulu olarak kabul edilmektedir. Çalışan mutluluğuna öncelik veren kuruluşlar, verimliliği artırmakta, üretimde artış sağlamakta ve hedeflere ulaşmaktadır. Sonuç olarak işte mutluluğun performans, örgütsel bağlılık, işe bağlılık, iş tatmini, kariyer başarısı ve yaratıcılık gibi örgütsel çıktılar üzerinde olumlu bir etkisi vardır (Ersoy ve Ehtiyar, 2017:379). Yani mutlu çalışanlar, mutsuz çalışanlara kıyasla daha enerjik ve iş yerine bağlılıkları iki kat daha fazladır. Mutlu çalışanlar aynı zamanda mutlu müşteriler yaratmaktadırlar. Özellikle hizmet işletmelerinde mutlu çalışanların yarattığı etkileri daha net gözlemleme imkânı söz konusudur (Demirbulat, Saatcı ve Aymankuy, 2019:2357).

Turizm sektörü, insanın insana yüz yüze hizmet verdiği emek yoğun bir sektördür. Bu kapsamda, müşteri memnuniyetinin sağlanmasında çalışanların memnuniyeti ve mutluğu büyük bir öneme sahiptir. Diğer bir deyişle, işinden ve hayatından memnun olan mutlu çalışanlar, müşterilerin mutluluğunu ve memnuniyetini de en üst düzeyde yerine getirebileceklerdir. Çünkü, turizm sektöründe görev yapan bireyler mutlu olmayı ve mutlu olmanın yollarını bilmiyorlarsa hizmet verirken başka insanları da mutlu edemeyeceklerdir. Bu nedenle, turizm çalışanlarının nasıl mutlu olunacağını bilmeleri ve dolayısıyla turistleri nasıl mutlu edeceklerini öğrenmeleri, profesyonel anlamda başarıları ve performansları üzerinde büyük bir etkiye sahip olacaktır. Sonuç olarak, mutlu çalışan mutlu müşteri demektir. Bu gerçekten hareketle, turizm işletmelerinin de sadece müşterilerin değil çalışanların da mutluluk ve memnuniyetlerinin hem iş hem de iş dışı ortamda sağlanması için gerekli tedbirleri alması sayesinde kurumdaki hizmet kalitesinin de artırılması mümkün olabilecektir.

Bunun yanında, çalışmada bazı kısıtlar da söz konusudur. Öncelikle çalışma sadece Manavgat'ta bulunan beş yıldızlı otel işletmelerinde gerçekleştirilmiştir. Çalışmanın daha farklı bölgelerdeki 
otellerde gerçekleştirilmesi yanında, seyahat acentaları, ulaşım ve yiyecek-içecek işletmeleri gibi turizm sektörünün farklı alanlarında uygulanması da önerilebilir. Sosyo-demografik değişkenler yanında mutluluğun örgütsel bağlllık, duygusal emek, iş doyumu gibi farklı değişkenlerle ilişkileri de incelenebilir. Bununla birlikte, Covid19 pandemisi öncesinde gerçekleştirilen bu çalışma ile pandemi döneminde turizm çalışanlarının mutluluk düzeyleri ölçülüp karşılaştırmalar yapılabilir. Ayrıca, daha derinlemesine bilgi edinebilmek için, bu tür nicel araştırmalar yanında nitel araştırmalar da literatüre önemli katkı sağlayabilecektir.

\section{KAYNAKÇA}

Ball, R. and Chernova, K. (2008). Absolute Income, Relative Income, and Happiness. Social Indicators Research, 88(3): 497-529.

Batz, C. and Tay, L. (2018). Gender Differences in Subjective Well-being. In E. Diener, S. Oishi, and L. Tay (Eds.), Handbook of Well-being. Salt Lake City, UT: DEF Publishers.

Batz-Barbarich, C., Tay, L., Kuykendall, L. and Cheung, H. K. (2018). A Meta-analysis of Gender Differences in Subjective Well-being: Estimating Effect Sizes and Associations with Gender Inequality, Psychological Science, 29(9): 1491-1503.

Beja, E.L. (2018). The U-shaped Relationship Between Happiness and Age: Evidence Using World Values Survey Data, Quality \& Quantity, 52: 1817-1829.

Binboğa, D. (2019). Duygusal Emek ve Öznel İyi Oluş İlişkisi: Kuşadası'nda Görev Yapan Turist Rehberleri Üzerinde Bir Araştırma, Yayınlanmamış Yüksek Lisans Tezi, Adnan Menderes Üniversitesi, Aydın.

Carr, A. (2004). Positive Psychology the Science of Happiness and Human Strengths. New York: Taylor \& Francis Group.

Castriota, S. (2006). Education and Happiness: A Further Explanation to The Easterling Paradox. CEIS Working Paper No. 246.

David, S. A., Boniwell, I. and Ayers, A. C. (2013). Conclusion: The Future of Happiness. In Oxford Handbook of Happiness.

Delle Fave, A., Brdar, I., Freire, T., Vella-Brodrick, D. and Wissing, M. P. (2011). The Eudaimonic and Hedonic Components of Happiness: Qualitative and Quantitative Finding, Social Indicators Research, 100(2): 185-207.

Demirbulat, Ö. G., Saatci, G. and Aymankuy, Y. A. (2019). A Conceptual Assessment on the Importance of Employee Happiness in Tourism Enterprises, OPUS Uluslararası Toplum Araştırmaları Dergisi, 13(19): 2345-2364.

De Neve, J. E., Diener, E., Tay, L. and Xuereb, C. (2013). The Objective Benefits of Subjective Wellbeing. In Helliwell, J., Layard, R. and Sachs, J. (Eds), World Happiness Report 2013 (Vol. 2, pp. 5479). New York: UN Sustainable Development Solutions Network.

Diener, E. (1984). Subjective Well-being, Psychological Bulletin, 95: 542- 575

Diener, E. (2000). Subjective Well-being: The Science of Happiness and a Proposal for a National Index, American Psychologist, 55(1): 34-43. 
Diener, E. (2006). Guidelines for National Indicators of Subjective Well-Being and Illbeing, Journal of Happiness Studies, 7(4): 397-404.

Diener, E. and Diener, M. (1995). Cross-cultural Correlates of Life Satisfaction and Self-Esteem, Journal of Personality and Social Psychology, 68: 653-663.

Diener, E., Gohm, C. L., Suh, E. and Oishi, S. (2000). Similarity of the Relations Between Marital Status and Subjective Well-being Across Cultures, Journal of Cross-Cultural Psychology, 31: 419-436.

Diener, E. and Lucas, R. E. (1999). Personality and Subjective Well-being. In D. Kahneman, E. Diener, and N. Schwarz (Eds.), Well-Being: The Foundations of Hedonic Psychology (pp. 213-229). New York: Russell Sage Foundation.

Diener, E., Ng, W. and Tov, W. (2008). Balance in Life and Declining Marginal Utility of Diverse Resources, Applied Research in Quality of Life, 3(4): 277-291.

Diener, E. and Ryan, K. (2009). Subjective Well-being: A General Overview, South African Journal of Psychology, 39(4): 391-406.

Diener, E., Suh, E. M., Lucas, E. and Smith, H. L. (1999). Subjective Well-being: Three Decades of Progress, Psychological Bulletin, 125(2): 276-302.

Doğan, T. ve Sapmaz, F. (2012). Oxford Mutluluk Ölçeği Türkçe Formunun Psikometrik Özelliklerinin Üniversite Öğrencilerinde İncelenmesi, Düşünen Adam Psikiyatri ve Nörolojik Bilimler Dergisi, 25: 297-304.

Doğan, T. ve Akıncı Çötok, N. (2011). Oxford Mutluluk Ölçeği Kısa Formunun Türkçe Uyarlaması: Geçerlik ve Güvenirlik Çalışması, Türk Psikolojik Danışma ve Rehberlik Dergisi, 4(36): $165-172$.

Ersoy, A. and Ehtiyar, R. (2017). Happiness at Work, In Efe, R., Penkova, R., Wendt, J. A., Saparov, K. T. and Berdenov, J. G. (Eds), Developments in Social Sciences, (v: 32, pp. 375-386), St. Kliment Ohridski University Press, Sofia.

Frey, B. S. and Stutzer, A. (2002). Happiness and Economics: How the Economy and Institutions Affect Human Well-Being. Princeton; Oxford: Princeton University Press.

Frijters, P. and Beatton, T. (2012). The Mystery of The U-shaped Relationship Between Happiness and Age, Journal of Economic Behavior \& Organization, 82(2-3): 525-542.

Gavin, J. H. and Mason, R. O. (2004). The Virtuous Organization: The Value of Happiness in the Workplace, Organizational Dynamics, 33(4): 379-392.

Graham, C. and Chattopadhyay, S. (2013). Gender and Well-Being Around the World, International Journal of Happiness and Development, 1(2): 212-232.

Haring, M. J., Stock, W. A. and Okun, M. A. (1984). A Research Synthesis of Gender and Social Class as Correlates of Subjective Well-being, Human Relations, 37(8): 645-657.

Haring-Hidore, M., Stock, W. A., Okun, M. A. and Witter, R. A. (1985). Marital Status and Subjective Well-being: A Research Synthesis, Journal of Marriage and the Family, 47(4): 947-953.

Hills, P. and Argyle, M. (2002). The Oxford Happiness Questionnaire: A Compact Scale for The Measurement of Psychological Well-being, Personality and Individual Differences, 33(7): 1073-1082. 
Inglehart, R. (2002). Gender, Aging, and Subjective Well-being, International Journal of Comparative Sociology, 43(3-5): 391-408.

Işık, Z., Çetinkaya, N. ve Işık, M. F. (2017). Mutluluğun İş Tatmini Üzerindeki Rolü: Erzurum İli Palandöken Kış Turizm Merkezinde Yer Alan Konaklama İşletmelerindeki Kadın Çalışanlar Üzerine Bir Uygulama, Atatürk Üniversitesi Sosyal Bilimler Enstitüsü Dergisi, 21(2): 457-471.

Kangal, A. (2013). Mutluluk Üzerine Kavramsal Bir Değerlendirme ve Türk Hane Halkı İçin Bazı Sonuçlar, Elektronik Sosyal Bilimler Dergisi, 12(44): 214-233.

Laaksonen, S. (2018). A Research Note: Happiness by Age is More Complex than U-Shaped, Journal of Happiness Studies, 19: 471-482.

Lyubomirsky, S., Sheldon, K. M. and Schkade, D. (2005). Pursuing Happiness: The Architecture of Sustainable Change, Review of General Psychology, 9(2): 111-131.

Lyubomirsky, S., King, L. and Diener, E. (2005). The Benefits of Frequent Positive Affect: Does Happiness Lead to Success?, Psychological Bulletin, 131(6): 803-855.

Lyubomirsky, S. and Kurtz, J. (2008). Positively Happy: Routes to Sustainable Happiness; A Six Week Course, UK: CreateSpace Independent Publishing Platform.

McGregor, I. and Little, B. R. (1998). Personal Projects, Happiness, and Meaning: On Doing Well and Being Yourself, Journal of Personality and Social Psychology, 74(2): 494-512.

Myers, D. G. (2000). The Funds, Friends, and Faith of Happy People, American Psychologist, 55(1): 56-67.

Niyazieva, S. and Zhechev, V. (2020). Could Happiness Be an Assessment Tool in Sustainable Tourism Management? Advances in Hospitality and Tourism Research, 8(2): 338-370.

Sheldon, K. M. and Lyubomirsky, S. (2007). Is it Possible to Become Happier? (And if so, How?) , Social and Personality Psychology Compass, 1(1): 129-145.

Sherman, A., Shavit, T., Barokas, G. and Kushnirovich, N. (2021). On The Role of Personal Values and Philosophy of Life in Happiness Technology, Journal of Happiness Studies, 22(3): 1055-1070.

Shmotkin, D. (1990). Subjective Well-Being as a Function of Age and Gender: A Multivariate Look for Differentiated Trends, Social Indicators Research, 23(3): 201-230.

Stack, S. and Eshleman, J. R. (1998). Marital Status and Happiness: A 17-Nation Study, Journal of Marriage and the Family, 60(2): 527-536.

Sürücü, Ö. (2016). İş Yaşantısında İyimserlik, Yaşam Doyumu ve Mutluluk; Otel İşletmelerinde Çalışan İş Görenlere Yönelik Bir Uygulama, Uluslararası Sosyal Araştırmalar Dergisi, 9(43): 21702176.

Veenhoven, R. (1997). Advances in Understanding Happiness, Revue Québécoise de Psychologie, 18(2): 29-74.

Witter, R. A., Okun, M. A., Stock, W. A. and Haring, M. J. (1984). Education and Subjective Wellbeing: A Meta-Analysis, Educational Evaluation and Policy Analysis, 6(2): 165-173.

Wood, W., Rhodes, N. and Whelan, M. (1989). Sex Differences in Positive Well-being: A Consideration of Emotional Style and Marital Status, Psychological Bulletin, 106(2): 249-264. 
Yurcu, G. ve Atay, H. (2015). Çalışanların Öznel İyi Oluşunu Etkileyen Demografik Faktörlerin İncelenmesi: Antalya İli Konaklama İşletmeleri Örneği, Manas Sosyal Araştırmalar Dergisi, 4(2): 17-34. 